BMJ Open

Diabetes

Research

\& Care

\title{
Treatment beliefs, health behaviors and their association with treatment outcome in type 2 diabetes
}

\author{
Lill-Brith Wium von Arx, ${ }^{1,3}$ Helge Gydesen, ${ }^{3}$ Søren Skovlund ${ }^{2}$
}

To cite: von Arx L-BW, Gydesen $\mathrm{H}$, Skovlund S. Treatment beliefs, health behaviors and their association with treatment outcome in type 2 diabetes. BMJ Open Diabetes Research and Care 2016;4:e000166. doi:10.1136/bmjdrc-2015000166

Received 24 October 2015 Revised 19 January 2016 Accepted 31 January 2016

\section{${ }^{1}$ Center for Health Economic Research (COHERE), University of Southern Denmark, Odense, Denmark ${ }^{2}$ Department of Health Economy and Outcomes Research, Novo Nordisk A/S, Søborg, Denmark ${ }^{3}$ Department of Epidemiology, Novo Nordisk A/S, Søborg, Denmark}

Correspondence to Dr Lill-Brith Wium von Arx; lbwr@novonordisk.com

\section{ABSTRACT}

Objective: While the prevalence of type 2 diabetes is growing, it is increasingly well recognized that treatment outcomes in primary care practice are often suboptimal. The aim of this study is to examine the extent to which treatment beliefs and health behaviors predict diabetes health outcome as measured by glycated hemoglobin $\left(\mathrm{HbA}_{1 \mathrm{c}}\right)$ level, blood pressure, and lipid profile.

Research design and methods: This was a largescale cross-sectional, registry-based study involving a well-defined type 2 diabetes population, in the county of Funen, Denmark. Registry data were combined with a 27-item self-reported survey administered to all insulin-treated people in the registry $(n=3160)$. The survey was constructed to operationalize key concepts of diabetes management, diabetes treatment beliefs, and health behaviors.

Results: In total, 1033 respondents answered the survey. The majority of treatment beliefs and health behaviors examined were predictors of glycemic control and, to a large extent, lipid profile. Absence from, or a low frequency of, self-measured blood glucose, non-adherence to general medical advice and the prescribed treatment, a low primary care utilization, and perceived low treatment efficacy were factors positively associated with $\mathrm{HbA}_{1 \mathrm{c}}$ levels, s-cholesterol, and low-density lipoprotein. Conversely, infrequent self-measured blood glucose was associated with a significantly higher likelihood of having a blood pressure below 130/80 $\mathrm{mm} \mathrm{Hg}$. Perceived low treatment efficacy was the only health belief associated with poorer levels of health outcome other than $\mathrm{HbA}_{1 \mathrm{c}}$. Conclusions: Health behaviors were stronger predictors for health outcomes than treatment beliefs. Self-reported adherence to either the treatment regimen or general medical advice most consistently predicted both glycemic control and cardiovascular risk factors.

\section{BACKGROUND}

Diabetes imposes significant demands on the person with the condition for ongoing daily self-management. Living with diabetes is often associated with psychosocial challenges. ${ }^{12}$ Optimal control involves day-to-day blood sugar monitoring, medication taking, lifestyle adjustment, preventing and managing long-term complications, coping with

\section{Key messages \\ - Self-reported adherence to therapy was found to be the most important patient reported predictor of both glycated hemoglobin and cardiovascular risk factors in people with diabetes in a large Danish sample. \\ - Treatment adherence was associated with improved overall life satisfaction and self-rated health. \\ - A personalized approach to diabetes care which considers the identified predictors of poor adher- ence and quality of life may be helpful for improving outcomes of type 2 diabetes manage- ment in primary practice.}

the psychosocial challenges attached to living with a chronic condition, and actively utilizing relevant diabetes support services.

Maintaining such health behaviors is a lifelong matter hampered by the fact that for many diabetes is a silent disease. That is, there are limited symptoms in daily life until the day that a complication occurs. This may be a long time after the initial diagnosis. Thus, instant rewards of disease selfmanagement are limited to intermediary treatment targets, such as blood sugar control. The actual health benefits, in terms of mitigating cardiovascular disease (CVD) or diabetes long-term sequela, remain a distant event emphasizing the everyday life diligence needed for optimal management.

The beliefs that people hold toward their current and future health, and their level of disease knowledge, are likely to modify the extent to which they engage in disease selfmanagement. The interplay between health beliefs, disease self-management, and health outcome was first delineated in the health belief model developed by US researchers in the 1950s. ${ }^{3}$ This model provides a conceptual framework for understanding disparities in why people do, or do not, engage in disease self-management. Engaging in health-related actions is predicted by the perceived value 
attached to an outcome and the perceived likelihood that these actions will lead to this outcome. ${ }^{4}{ }^{5}$ Other social cognition theories developed to predict health behavior include self-efficacy theory ${ }^{6}$ and the theory of planned behavior. ${ }^{7}$ Treatment outcomes examined in previous applications of these theories include adherence in diabetes ${ }^{4-12}$ and glycemic control. ${ }^{13-20}$ Only two studies included a composite measure of metabolic control reflecting both glycemic control and cardiovascular risk. $^{21} 22$

The aim of this study is to examine the extent to which different beliefs and behaviors related to diabetes predict health outcomes. This was a large-scale crosssectional study involving people with type 2 diabetes in the county of Funen, Denmark. Health outcome was indicated by glycated hemoglobin $\left(\mathrm{HbA}_{1 \mathrm{c}}\right)$ level, blood pressure (BP), total serum cholesterol (s-cholesterol), and low-density lipoprotein (LDL) cholesterol. The health information available from the disease registry was supplemented with self-reported demographic and psychometric data from a questionnaire administered to all insulin-treated people in the registry $(n=3160)$.

The significance of this study can be assessed via the use of registry-based health data from a well-defined population of insulin users and the evaluation of diabetes health outcomes reflecting cardiovascular outcomes and glycemic control. The results provide direction for targeting diabetes care to patient segments in particular need of education and self-management support. The conceptual framework may be generalized to a practitioner setting and is particularly relevant for developing screening strategies in primary and secondary diabetes care.

\section{RESEARCH DESIGN AND METHODS}

This study was a cross-sectional registry study combined with a postal survey of patients with type 2 diabetes in Denmark.

Funens Diabetes Database (FDDB) is a disease registry established in 2003 and is employed by medical outpatient clinics, general practitioners (GP) and ophthalmologists in Funen. Approximately 9000 patients with diabetes are registered in the database. Laboratory analyses are performed at local laboratories and are automatically transferred to the registry. Other information is entered manually by healthcare professionals. ${ }^{23}$

A 27-item questionnaire was developed to supplement the health information contained in the registry. These items were constructed to operationalize the key concepts detailed in the research question, diabetes treatment beliefs and health behavior. The construction of items was based on the domains of the health belief model $^{3}$ and self-efficacy theory. ${ }^{6}$ A discrete choice experiment on patient preference toward the benefit-risk profile of diabetes treatment formed part of the questionnaire, but this analysis is not relevant to this paper.
The generation of items was an iterative process. Initially, one-to-one interviews were conducted with diabetes specialists $(n=2)$, a diabetes nurse, a diabetes education specialist and people with diabetes $(n=3)$ to identify topics and items to be included. Two focus groups, each with four participants, were conducted to ensure face validity, acceptability, and clarity of the questionnaire items, and logic of the overall order in which the items were presented. All participants were insulin users, and were recruited through a diabetes clinic at Hilleroed Hospital, Denmark. Focus group participants were invited to share their thoughts on the questionnaire during a $2 \mathrm{~h}$ session.

To enable a systematic appraisal of the questionnaire performance, the revised questionnaire was piloted using a small sample of intended respondents. Written comments on the questionnaire were assessed and changes implemented accordingly. In some cases, response options were modified to prevent indications of ceiling or flooring effects of a particular scale.

\section{Study population}

The questionnaire was sent by postal mail to all insulin users with type 2 diabetes in the registry $(n=3160)$ with a prepaid return envelope included. A unique identifier was assigned by FDDB to ensure respondent anonymity and allow linkage between the self-reported and register data.

Respondents were informed that by answering the questionnaire, consent was given to obtain information from their registered health information. No remuneration was offered for participation. Access to the registry was contingent on study approval by the Danish data protection agency and the registry steering committee.

\section{Diabetes registry}

Health information derived from the registry is depicted in table 1. The International Federation of Clinical Chemistry (IFCC) $\mathrm{HbA}_{1 \mathrm{C}}$ values were converted to the Diabetes Control and Complication Trial (DCCT) standard values using the following formula: $(0.09148 *$ IFCC) $+2.152 .{ }^{24}$

The Danish treatment guidelines for type 2 diabetes were used to define health outcome. For patients with type 2 diabetes without CVD, these are $\mathrm{HbA}_{1 \mathrm{c}}<6.5 \%$ $(<47.5 \mathrm{mmol} / \mathrm{mol})$, s-cholesterol $<4.5 \mathrm{mmol} / \mathrm{L}$, LDLcholesterol $<2.5 \mathrm{mmol} / \mathrm{L}$, and $\mathrm{BP}<130 / 80 \mathrm{~mm} \mathrm{Hg}$. For patients with or at high risk of CVD, the recommendations are $\mathrm{HbA}_{1 \mathrm{c}}<7.5 \%(<58.5 \mathrm{mmol} / \mathrm{mol})$, s-cholesterol $<4.0 \mathrm{mmol} / \mathrm{L}$, and LDL-cholesterol $<2 \mathrm{mmol} / \mathrm{L}$ $(\mathrm{BP}<125 / 75 \mathrm{~mm} \mathrm{Hg}$ in renal disease $) .^{25}$

To evaluate the CVD risk of the sample population, a type 2 diabetes-specific equation for estimation of 5-year first incident fatal/non-fatal CVD was calculated using the formula, 5-year risk $(\mathrm{CVD})^{26}=\left(1-\exp \quad\left[-\left(\mathrm{q}_{5}\right.\right.\right.$

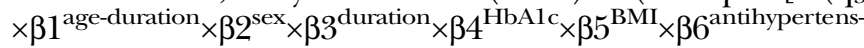
ive drugs $\times \beta$ 7systolic blood pressure $\left.\left.\times \beta 8^{\text {lipid lowering drugs }} \times \beta 9^{\text {smoker }}\right)\right]$ ) $\times 100$. 
Table 1 Domains in the survey instrument and diabetes registry

\begin{tabular}{|c|c|c|c|}
\hline Domain & Survey instrument & Scale & Diabetes registry \\
\hline \multirow[t]{4}{*}{ Sociodemographic } & Education & 7 Categories & Age \\
\hline & Occupation & 7 Categories & Sex \\
\hline & Household and own income & $\begin{array}{l}1 \text { (Below 149K DKK) } \\
\text { to } 7 \text { (>850K DKK) }\end{array}$ & $\begin{array}{l}\text { Weight }(\mathrm{kg}) / \text { height }(\mathrm{cm}) \\
\mathrm{BMI}\end{array}$ \\
\hline & Health insurance & Yes/no & $\begin{array}{l}\text { Duration of diabetes } \\
\text { (years) }\end{array}$ \\
\hline \multicolumn{4}{|l|}{ Health status } \\
\hline Measurements & $\begin{array}{l}\text { Self-measured BG (mmol/L) after questionnaire } \\
\text { completion }\end{array}$ & $<5$ to $>18 \mathrm{mmol} / \mathrm{L}$ & $\begin{array}{l}\mathrm{HbA}_{1 \mathrm{c}}(\%) \\
\mathrm{LDL}(\mathrm{mmol} / \mathrm{L}) \\
\mathrm{HDL}(\mathrm{mmol} / \mathrm{L} \\
\text { S-cholesterol }(\mathrm{mmol} / \mathrm{L}) \\
\text { Systolic BP }(\mathrm{mm} \mathrm{Hg}) \\
\text { Diastolic BP }(\mathrm{mm} \mathrm{Hg})\end{array}$ \\
\hline $\begin{array}{l}\text { Mental/physical } \\
\text { health }\end{array}$ & $\begin{array}{l}\text { Limitation during physical activity (self-rated NYHA } \\
\text { class I-IV) } \\
\text { Well-being and mobility } \\
\text { Life satisfaction }\end{array}$ & $\begin{array}{l}\text { Multiple choice } \\
\text { ( } 4 \text { health states) } \\
\text { EQ-5D } \\
1 \text { (very dissatisfied) } \\
\text { to } 10 \text { (very satisfied) }\end{array}$ & \\
\hline $\begin{array}{l}\text { Severe } \\
\text { complications }\end{array}$ & $\begin{array}{l}\text { Severe hypoglycemia } \\
\text { Night-time hypoglycemia }\end{array}$ & $\begin{array}{l}\text { (total number) } \\
\text { (yes/no) }\end{array}$ & $\begin{array}{l}\text { Severe hypoglycemia } \\
\text { (total number) } \\
\text { Ketoacidosis } \\
\text { (total number) } \\
\text { Retinopathy } \\
\text { Foot risk } \\
\text { Foot ulcer } \\
\text { Amputation } \\
\text { Kidney failure (yes/no) } \\
\text { Apoplexy (total } \\
\text { number) } \\
\text { Vascular operation } \\
\text { (total number) } \\
\text { Angina (yes/no) } \\
\text { Heart failure (yes/no) }\end{array}$ \\
\hline $\begin{array}{l}\text { Minor } \\
\text { complications }\end{array}$ & Minor hypoglycemic events & (per month) & - \\
\hline Treatment regimen & - & - & $\begin{array}{l}\text { Insulin regimen } \\
\text { Antihypertensive } \\
\text { treatment } \\
\text { Antilipidemic treatment }\end{array}$ \\
\hline \multicolumn{4}{|l|}{ Health behavior } \\
\hline Daily habits & $\begin{array}{l}\text { Exercise (intensity/frequency) } \\
\text { Smoker } \\
\text { Home measured BG }\end{array}$ & $\begin{array}{l}1 \text { (high) to } 4 \text { (low) } \\
\text { Yes/no } \\
\text { (number per week) }\end{array}$ & - \\
\hline Self-efficacy & $\begin{array}{l}\text { Own ability to engage in health promoting actions: } \\
\text { (1) diet, (2) exercise, (3) dentist visits, (4) GP } \\
\text { advice adherence (5) visiting one's GP (primary } \\
\text { care utilization), (6) treatment adherence }\end{array}$ & $\begin{array}{l}1 \text { (Poor) to } 10 \\
\text { (very good) }\end{array}$ & - \\
\hline $\begin{array}{l}\text { Treatment } \\
\text { adherence }\end{array}$ & Level of treatment adherence & $\begin{array}{l}1 \text { (not at all) to } 4 \\
\text { (fully) }\end{array}$ & - \\
\hline \multicolumn{4}{|l|}{ Health beliefs } \\
\hline $\begin{array}{l}\text { Susceptibility to } \\
\text { health risk }\end{array}$ & $\begin{array}{l}\text { Familiarity with } \mathrm{HbA}_{1 \mathrm{c}} \\
\text { Understanding of } \mathrm{HbA}_{1 \mathrm{c}} \text { and its association with } \mathrm{BG} \\
\text { in the past } 3 \text { months } \\
\text { Satisfactory } \mathrm{HbA}_{1 \mathrm{c}} \text { level } \\
\text { Perception of own heart health/condition }\end{array}$ & $\begin{array}{l}\text { Yes/no/do not know } \\
\text { Multiple choice } \\
\text { ( } 3 \text { statements) } \\
\mathrm{HbA}_{1 \mathrm{c}} 5.5-10 \% \\
1 \text { (poorest) to } 10 \\
\text { (best possible) }\end{array}$ & $\begin{array}{l}- \\
- \\
-\end{array}$ \\
\hline
\end{tabular}


Table 1 Continued

\begin{tabular}{llll}
\hline Domain & Survey instrument & Scale & Diabetes registry \\
\hline $\begin{array}{l}\text { Severity of } \\
\text { diabetes }\end{array}$ & $\begin{array}{l}\text { Specifying where damage may occur due to poor } \\
\text { glucose control (hands, feet, heart, kidneys, eyes, } \\
\text { teeth/gums) }\end{array}$ & Yes/no/do not know & - \\
$\begin{array}{l}\text { Barriers toward } \\
\text { (1) finding the treatment cumbersome, (2) }\end{array}$ & $\begin{array}{l}\text { 1 (disagree) to 5 } \\
\text { (very much agree) }\end{array}$ & - \\
time-consuming or (3) skipping treatments due to & (vinancial burden \\
Benefits of & $\begin{array}{l}\text { (1) finding it does not improve one's condition much } \\
\text { and (2) feeling well despite not always following the } \\
\text { treatment }\end{array}$ & (very much agree) & - \\
\hline
\end{tabular}

BG, blood glucose; BMI, body mass index; BP, blood pressure; DKK, Danish Krone; EQ-5D, EuroQOL five dimensions questionnaire; GP, general practitioner; $\mathrm{HbA}_{1 \mathrm{c}}$, glycated hemoglobin; HDL, high-density lipoprotein; LDL, low-density lipoprotein; NYHA, New York Heart Association.

\section{Self-reported questionnaire data}

Health behavior was evaluated through questions on dietary habits, smoking, exercise, treatment adherence, self-measured blood glucose (SMBG) testing, and respondent primary care utilization. The scale used for these questions was ordinal (eg, Q: 'To what extent do you comply with your diabetes treatment?' A: 'not at all, to some extent, to a high extent, fully'). Others were presented as a scale from 1 to 10 ( $1=$ very poor and $10=$ very good), for example, 'How good/poor are you at doing what you know is best for you?'. Respondents then had to answer this for 6 different behaviors related to diet, exercise, keeping to dentist/GP visits, taking one's medication, and adhering to medical advice.

Treatment beliefs were assessed through questions examining respondents' attitudes toward treatment and understanding of diabetes. Treatment attitudes were stated on an ordinal scale (very much disagree to very much agree), for example, 'The treatment doesn't improve my diabetes much'. The respondent's understanding of $\mathrm{HbA}_{1 \mathrm{c}}$ was revealed with a set of questions on whether the respondents (1) had heard of $\mathrm{HbA}_{1 \mathrm{c}}$ before (yes/no), (2) could identify the correct answer out of three on the interpretation of $\mathrm{HbA}_{1 \mathrm{c}}$ as a longterm marker of blood glucose control (multiple choice), and (3) could state their $\mathrm{HbA}_{1 \mathrm{c}}$ target within a range of values between $5.5 \%$ and $10 \%$ (multiple choice). Respondent understanding of long-term sequela was revealed by a multiple choice question (yes/no/do not know) asking the respondents to mark the places where one is at risk of damage due to prolonged high blood sugar (hands, feet, heart, kidneys, eyes, teeth/gums).

The classification of level of education and occupation were guided by standards commonly used in Denmark. ${ }^{27} 28$ All questionnaire domains are mapped against the registry data in table 1 .

\section{Statistical analysis}

SAS for Windows V.9.3 (SAS Institute Inc, Cary, North Carolina, USA) was used for data management and statistical analysis. Relevant variables were categorized, and descriptive statistics were shown as a number and percentage for each variable level. The Danish EuroQOL five dimensions questionnaire (EQ-5D) valuation algorithm ${ }^{29}$ was used to calculate a single index score for all five EQ-5D dimensions.

Forward stepwise multiple regressions were performed, regressing a dependent variable on a set of potential explanatory variables in a one-by-one manner. The explanatory variables included in these analyses were: age, gender, body mass index (BMI), duration of diabetes, insulin regimen, smoking status, education, income, self-reported New York Heart Association (NYHA) class, physical activity level, EQ-5D score, and life satisfaction. The health outcomes regressed were: $\mathrm{HbA}_{1 \mathrm{c}}$, s-cholesterol, LDL, and systolic BP.

Subsequently, the variable most strongly associated with a dependent variable was identified and included in models against each of the dependent variables. The variables explaining the largest amount of the remaining variation was kept in the models.

Normal plots of residuals from the regression models were made, and the data log-transformed if needed. For descriptive purposes, the arithmetic mean and CIs calculated from log-transformed data were adjusted back to their original scale through exponentiation. ${ }^{30}$

Logistic regression analyses were used to estimate odds ratios (ORs) for meeting diabetes treatment goals in the presence of prespecified diabetes management behaviors or treatment beliefs. These were included in logistic regression analyses if significant at the 0.15 level for more than one of the health outcomes in the individual regression analyses. This level of significance was selected to ensure that all relevant behaviors and beliefs were tested in logistic regression models.

The aim of the analyses was to examine the association between health outcome $\left(\mathrm{HbA}_{1 \mathrm{c}}\right.$, s-cholesterol, LDL, and $\mathrm{BP}$ ), treatment beliefs, and health behavior. To support these findings, subanalyses on predictors of beliefs and behavior were performed. Behaviors and beliefs significantly associated with meeting more than one treatment target were regressed individually on relevant explanatory factors in backward stepwise logistic regression. The background data selected for these 
analyses were age, gender, BMI, smoking status, insulin regimen, duration of diabetes, self-reported NYHA class and heart health, EQ-5D score and life satisfaction, minor and major hypoglycemic events, income and education.

\section{RESULTS}

Of the 3160 distributed questionnaires, one-third $(1031 / 33.3 \%)$ were returned. Age was the only variable available on non-responders, but did not differ significantly from the respondent group $(66 \pm \mathrm{SD} 13$ vs $67 \pm \mathrm{SD}$ $11)$.

The average respondent was male, 67 years of age, diagnosed with diabetes for 15 years and with $\mathrm{HbA}_{1 \mathrm{c}}$, LDL, and cholesterol levels slightly above recommendations. More than half had high BP. The combination of long-term diabetes, elevated $\mathrm{HbA}_{1 \mathrm{c}}$ and cholesterol levels, being overweight, and hypertension induced an average 5-year cardiovascular event risk of $27 \%$. Since most respondents were elderly and at risk of CVD, the treatment target recommended for this population was applied in all logistic regression analyses.

Approximately two-thirds of the respondents were outside the labor market. The majority $(69 \%)$ were of a low education level (highest degree high school or technical college) with a household income of $<250000$ Danish Kroner (DKK) (75\%). Intermediary diabetes damage (eyes or feet) affected up to $46 \%$ of the respondents. Terminal damage (amputation or renal failure) affected $5 \%$ of the respondents (table 2).

Log-transformations were made for all health outcomes, except systolic BP. Covariates significantly associated with any treatment outcome at the 0.05 level in linear and logistic regression analyses were: duration of diabetes, insulin regimen, smoking, age, self-reported NYHA class, gender, and age. Results for linear regression analyses in which each health outcome $\left(\mathrm{HbA}_{1 \mathrm{c}}\right.$, systolic BP, s-cholesterol, and LDL) was regressed on health behaviors and treatment beliefs are shown in tables 3 and 4 .

\section{Diabetes treatment beliefs}

More than half of the respondents were satisfied with an $\mathrm{HbA}_{1 \mathrm{c}}$ level below $7.5 \%$. The majority of respondents had heard of $\mathrm{HbA}_{1 \mathrm{c}}$ previously. A minority of $4 \%$ thought that the $\mathrm{HbA}_{1 \mathrm{c}}$ measurement correlated with the self-measured morning blood glucose measured the same day. One-third did not associate heart disease with diabetes management. Neuropathy and its related damage to feet was known by most respondents (91.7\%) but not damage to hands $(24.5 \%)$ (table 5 ).

Approximately one-third (34\%) found their treatment cumbersome and 22\% stated that it did not improve their diabetes much (perceived low treatment efficacy) or found the treatment very time-consuming. A small number of respondents (12\%) could not reject budget constraints as a reason for sometimes skipping
Table 2 Demography and health $(n=1033)$

Age, mean (SD)

Male sex, $\mathrm{n}(\%)$

$\mathrm{BMI}$, mean (SD)

$\mathrm{EQ}-5 \mathrm{D}$, mean (SD)

$\mathrm{HbA}_{1 \mathrm{c}}(\%)$, mean (SD)

$\mathrm{HbA}_{1 \mathrm{c}} \mathrm{mmol} / \mathrm{mol}$, mean (SD)

LDL mmol/L, mean (SD)

S-cholesterol $\mathrm{mmol} / \mathrm{L}$, mean (SD)

Diabetes duration, years, mean (SD)

5-year CVD event risk, mean (SD)

High BP (>130/80 mm Hg), n (\%)

Smoker, n (\%)

Hypoglycemic events, $n(\%)$

Non-severe, the past week None

$1-5$

$>6$

Severe, in a lifetime, $\mathrm{n}(\%)$

None

1

$>1$

Self-measured blood glucose, per week, $\mathrm{n}(\%)$

None/do not know

1-6

7 or more

Complications, $\mathrm{n}(\%)$

Foot wound

Amputation (foot/leg)

Retinopathy, mild

Retinopathy, severe

Renal failure

Heart failure, $\mathrm{n}(\%)$

Vascular surgery, $\mathrm{n}(\%)$

Education, $\mathrm{n}(\%)$

Primary school/high school

Technical college

Medium length ( $\leq 4$ years)

Higher education ( $\geq 5$ years)

Income (DKK), n (\%)

Up to 149000

150 000-249000

250 000-374000

375000 and above

Labor market attachment, $\mathrm{n}$ (\%)

None

Other (undefined)

Unskilled worker

Skilled worker

Self-employed

Official/white-collar worker

$352(45.2)$

$377(48.5)$

$33(4.3)$

$61(78.9)$

$81(10.4)$

$73(9.4)$

$174(21.8)$

$317(39.8)$

$183(23.0)$

$58(5.8)$

$19(1.9)$

$353(35.2)$

$50(5.0)$

$43(4.6)$

$36(4.5)$

$65(6.7)$

$361(39.0)$

289 (31.1)

$233(25.1)$

$45(4.9)$

$372(39.6)$

$324(34.5)$

$139(14.8)$

$104(11.1)$

$798(79.6)$

$40(4.0)$

$33(3.3)$

34 (3.4)

$41(4.1)$

$57(5.7)$

BMI, body mass index; BP, Blood Pressure; CVD, cardiovascular disease; DKK, Danish Krone; EQ-5D, EuroQOL five dimensions questionnaire; $\mathrm{HbA}_{1 \mathrm{c}}$, glycated hemoglobin; LDL, low-density lipoprotein.

treatment. Higher $\mathrm{HbA}_{1 \mathrm{c}}$ levels were associated with perceived low treatment efficacy and the belief that an $\mathrm{HbA}_{1 \mathrm{c}}$ level above 7.5 was satisfactory. The treatment beliefs included in linear regression analyses are shown in table 3. 


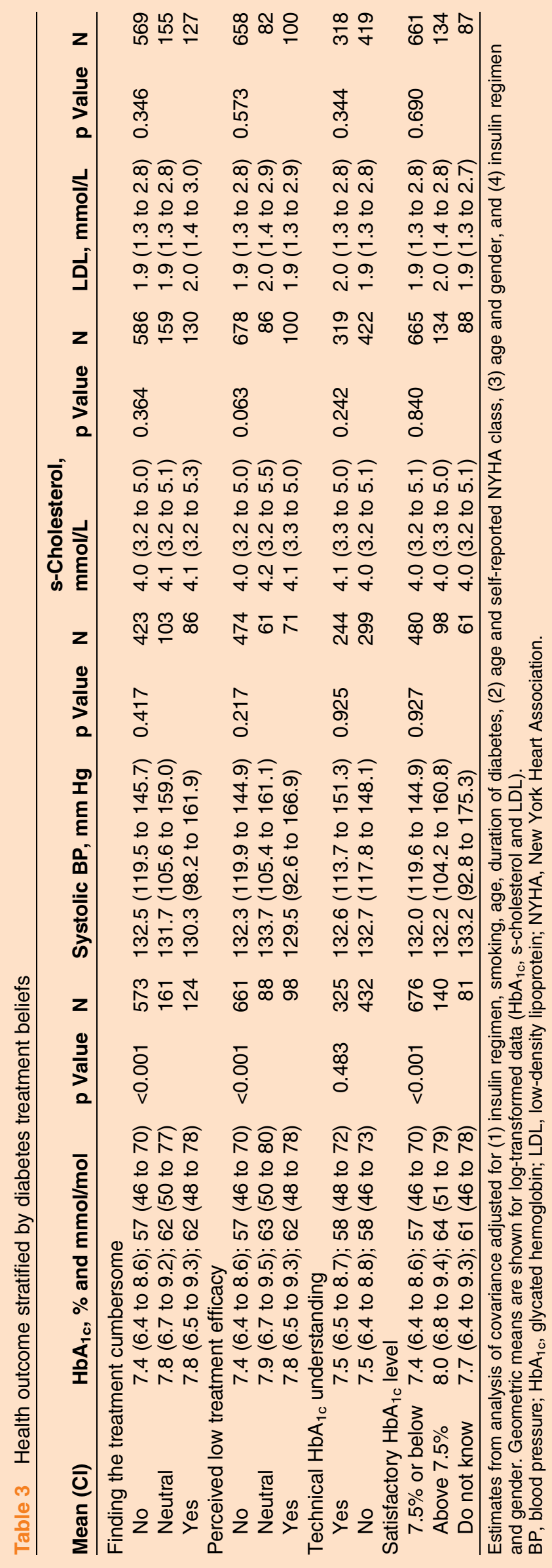

Perceived low treatment efficacy was the only health belief associated with other treatment outcomes than $\mathrm{HbA}_{1 \mathrm{c}}$. Thus, people who did not reject the statement 'The treatment doesn't better my diabetes much' were $30 \%$ and $40 \%$ less likely to have s-cholesterol $<4 \mathrm{mmol} / \mathrm{L}$ (OR 0.7 , CI 0.5 to 1.0 ) or $\mathrm{HbA}_{1 \mathrm{c}}<7.5 \%$ $(58.5 \mathrm{mmol} / \mathrm{mol})$ (OR 0.6, CI 0.5 to 0.9$)$.

\section{Health behaviors}

With the exception of eating habits and exercise, the majority of respondents stated a high self-efficacy within the domains of primary care utilization and adherence. To the question 'How good are you at doing what you know is best for you?', the distribution of answers of eight or more (on a scale of 1 (poor) to 10 (very good)) was: visiting my dentist $(71 \%)$, visiting my GP $(82 \%)$, following my GP's advice $(89 \%)$, and taking my medication $(95 \%)$. In a multiple choice questionnaire item, $78 \%$ stated that they were either fully or to a large extent adhering to their treatment. More than half of the respondents measured their blood glucose at home at least once a week (table 2).

The majority were non-smokers (table 2), and more than half of the sample $(628 ; 63.2 \%)$ was moderately active at least $4 \mathrm{~h} /$ week. A minority reported intense exercise of $4 \mathrm{~h} /$ week $(27 ; 2.7 \%)$ and one-third (339; 34.1) were sedentary. Approximately two-thirds exercised at least $4 \mathrm{~h}$ /week (table 1). All health behaviors, apart from being a smoker, were significantly associated with lower mean $\mathrm{HbA}_{1 \mathrm{c}}$ levels. Frequency of SMBG, adherence to general medical advice or the treatment itself, and primary care utilization were significantly associated with both $\mathrm{HbA}_{1 \mathrm{c}}$ and lipid profile in linear regression analyses (table 4).

Respondents stating a low adherence with either general medical advice or their treatment regimen were $40-60 \%$ less likely to meet their $\mathrm{HbA}_{1 \mathrm{c}}$ goal (OR 0.4, CI 0.3 to 0.6 and OR 0.6 , CI 0.4 to 0.8 ) of $7.5 \%$ $(58.5 \mathrm{mmol} / \mathrm{mol})$ and $30 \%$ less likely to meet their LDL goal (OR 0.7, CI 0.5 to 1.0 and OR 0.7, CI 0.5 to 1.0 ) of $2 \mathrm{mmol} / \mathrm{L}$.

Infrequent SMBG decreased the likelihood of meeting an $\mathrm{HbA}_{1 \mathrm{c}}$ target (OR 0.6, CI 0.4 to 1.9) of $7.5 \%$ ( $58.5 \mathrm{mmol} / \mathrm{mol}$ ), s-cholesterol (OR 0.7 , CI 0.4 to 1.0 ) of $4 \mathrm{mmol} / \mathrm{L}$, and LDL recommendations (OR 0.6, CI 0.4 to 1.0 ) of $2 \mathrm{mmol} / \mathrm{L}$ or below, but conversely induced an $80 \%$ higher likelihood of having a BP (OR 1.8, CI 1.1 to 3.0) below $130 / 80 \mathrm{~mm} \mathrm{Hg}$.

Low self-reported primary care utilization was significantly associated with having an $\mathrm{HbA}_{1 \mathrm{c}}$ below $7.5 \%$, $58.5 \mathrm{mmol} / \mathrm{mol}$ (OR 0.8 , CI 0.6 to 1.0 ) but no other health outcome.

\section{Predictors of treatment belief and health behavior}

Adherence to either the treatment regimen or general medical advice, as well as SMBG, was significantly associated with a higher likelihood of meeting the treatment target for both $\mathrm{HbA}_{1 \mathrm{c}}$ and $\mathrm{BP}$ and lipid profile. Thus, 
Table 4 Health outcome stratified by diabetes health behavior

\begin{tabular}{|c|c|c|c|c|c|c|c|c|c|c|c|c|}
\hline Mean (Cl) & $\mathrm{HbA}_{1 \mathrm{c}}, \%$ and $\mathrm{mmol} / \mathrm{mol}$ & p Value & $\mathbf{N}$ & Systolic BP, mm Hg & p Value & $\mathbf{N}$ & $\begin{array}{l}\text { s-Cholesterol, } \\
\mathrm{mmol} / \mathrm{L}\end{array}$ & p Value & $\mathbf{N}$ & LDL, $\mathrm{mmol} / \mathrm{L}$ & p Value & $\mathbf{N}$ \\
\hline \multicolumn{13}{|c|}{ Weekly self-measured blood glucose } \\
\hline $\begin{array}{l}\text { None/do not } \\
\text { know }\end{array}$ & 7.9 (6.5 to 9.6$) ; 63$ (48 to 81 ) & 0.018 & 107 & $130.1(100.2$ to 161.5$)$ & 0.559 & 72 & $4.2(3.4$ to 5.3$)$ & \multirow[t]{3}{*}{0.124} & 110 & 2.0 (1.5 to 2.8$)$ & \multirow[t]{3}{*}{0.224} & 109 \\
\hline $\begin{array}{l}1-7 \text { times a } \\
\text { week }\end{array}$ & 7.4 (6.4 to 8.7$) ; 57$ (46 to 72 ) & & 382 & $132.3(115.2$ to 149.7$)$ & & 260 & 4.0 (3.2 to 5.0$)$ & & 383 & $1.9(1.2$ to 2.8$)$ & & 382 \\
\hline $\begin{array}{l}1-3 \text { times a day } \\
\text { or more }\end{array}$ & 7.5 (6.5 to 8.6 ); 58 (48 to 70 ) & & 405 & $132.4(116.9$ to 148.2$)$ & & 324 & 4.0 (3.2 to 5.0$)$ & & 419 & $1.9(1.3$ to 2.8$)$ & & 416 \\
\hline \multicolumn{13}{|c|}{ Treatment adherence } \\
\hline Low/moderate & 7.9 (6.7 to 9.5$) ; 63$ (50 to 80$)$ & \multirow{2}{*}{$<0.001$} & 186 & 132.4 (129.9 to 135.0$)$ & 0.783 & 123 & 4.1 (3.2 to 5.3$)$ & \multirow{2}{*}{0.114} & 189 & $2.0(1.4$ to 2.9$)$ & \multirow{2}{*}{0.120} & 184 \\
\hline Average/high & 7.4 (6.4 to 8.6$) ; 57$ (46 to 70 ) & & 705 & $132.2(131.1$ to 133.5$)$ & & 518 & $4.0(3.2$ to 5.0$)$ & & 730 & $1.9(1.3$ to 2.8$)$ & & 711 \\
\hline \multicolumn{13}{|c|}{ Medical advice adherence } \\
\hline Low/moderate & 8.0 (6.8 to 9.4$) ; 64$ (51 to 79$)$ & \multirow{2}{*}{$<0.001$} & 226 & $132.0(110.6$ to 153.4$)$ & 0.587 & 162 & 4.1 (3.3 to 5.2$)$ & \multirow[t]{2}{*}{0.040} & 233 & $2.0(1.4$ to 2.9$)$ & \multirow{2}{*}{0.017} & 223 \\
\hline Average/high & 7.4 (6.4 to 8.6$) ; 57$ (46 to 70 ) & & 653 & 132.3 (119.4 to 145.2$)$ & & 469 & 4.0 (3.2 to 5.0$)$ & & 672 & $1.9(1.3$ to 2.8$)$ & & 658 \\
\hline \multicolumn{13}{|l|}{ Smoker } \\
\hline Yes & 7.5 (6.4 to 8.7$) ; 58$ (46 to 72 ) & \multirow[t]{2}{*}{0.433} & 761 & 130.5 (120.7 to 144.5$)$ & 0.359 & 102 & $4.0(3.2$ to 5.1$)$ & \multirow{2}{*}{0.890} & 134 & $1.9(1.3$ to 2.8$)$ & \multirow{2}{*}{0.278} & 132 \\
\hline No & 7.7 (6.4 to 9.2$) ; 61$ (46 to 77 ) & & 139 & 132.5 (103.2 to 158.5$)$ & & 529 & $4.0(3.2$ to 5.0$)$ & & 772 & $2.0(1.4$ to 2.8$)$ & & 749 \\
\hline \multicolumn{13}{|c|}{ Primary care utilization } \\
\hline Low/moderate & 7.7 (6.6 to 9.0$) ; 61$ (49 to 75 ) & \multirow[t]{2}{*}{0.028} & 323 & $132.2(115.2$ to 149.6$)$ & 0.414 & 168 & 4.1 (3.2 to 5.2$)$ & \multirow[t]{2}{*}{0.250} & 230 & $2.0(1.3$ to 2.9$)$ & \multirow{2}{*}{0.133} & 229 \\
\hline Average/high & 7.4 (6.4 to 8.7$) ; 57$ (46 to 72$)$ & & 553 & $132.0(117.6$ to 146.3$)$ & & 472 & 4.0 (3.2 to 5.0$)$ & & 664 & $1.9(1.3$ to 2.7$)$ & & 660 \\
\hline \multicolumn{13}{|c|}{ Maintaining healthy eating habits } \\
\hline Low/moderate & 7.8 (6.7 to 9.2$) ; 62$ (50 to 77 ) & \multirow[t]{2}{*}{0.002} & 135 & $131.4(102.3$ to 160.6$)$ & 0.867 & 90 & 4.1 (3.3 to 5.1$)$ & \multirow[t]{2}{*}{0.298} & 136 & $2.0(1.4$ to 2.7$)$ & \multirow{2}{*}{0.561} & 132 \\
\hline Average/high & 7.5 (6.4 to 8.7$) ; 58$ (46 to 72 ) & & 746 & 132.3 (120.7 to 144.2$)$ & & 532 & $4.0(3.2$ to 5.0$)$ & & 758 & $1.9(1.3$ to 2.8$)$ & & 738 \\
\hline \multicolumn{13}{|l|}{ Exercise } \\
\hline Low/moderate & 7.7 (6.5 to 9.1 ); 61 (48 to 76 ) & \multirow[t]{2}{*}{0.008} & 332 & $132.4(111.2$ to 153.8$)$ & 0.824 & 234 & $4.0(3.2$ to 5.1$)$ & \multirow[t]{2}{*}{0.729} & 336 & 1.9 (1.3 to 2.8$)$ & \multirow[t]{2}{*}{0.307} & 326 \\
\hline Average/high & $7.4(6.4$ to 8.6$) ; 57$ (46 to 70$)$ & & 554 & 132.1 (119.8 to 144.5$)$ & & 390 & 4.0 (3.2 to 5.0$)$ & & 563 & $1.9(1.3$ to 2.8$)$ & & 549 \\
\hline \multicolumn{13}{|c|}{$\begin{array}{l}\text { Estimates from analysis of covariance adjusted for (1) insulin regimen, smoking, age, duration of diabetes, (2) age and self-reported NYHA class, (3) age and gender, and (4) insulin regimen } \\
\text { and gender. Geometric means are shown for log-transformed data ( } \mathrm{HbA} \mathrm{A}_{10}, \mathrm{~s} \text {-cholesterol and LDL). } \\
\mathrm{BP} \text {, blood pressure; } \mathrm{HbA} \mathrm{A}_{10} \text {, glycated hemoglobin; LDL, low-density lipoprotein; NYHA, New York Heart Association. }\end{array}$} \\
\hline
\end{tabular}

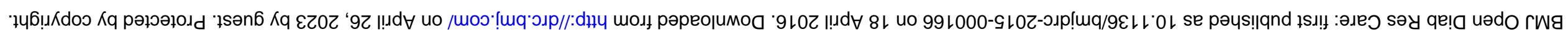


Table 5 Respondent understanding of $\mathrm{HbA}_{1 \mathrm{c}}$ and diabetes long-term complications

\begin{tabular}{|c|c|}
\hline & $\mathbf{N}(\%)$ \\
\hline \multicolumn{2}{|l|}{ Satisfactory $\mathrm{HbA}_{1 \mathrm{c}}$ level } \\
\hline$<6.5 \%(48 \mathrm{mmol} / \mathrm{mol})$ & $164(16.6)$ \\
\hline $6.5-7.4 \%(48-57 \mathrm{mmol} / \mathrm{mol})$ & $447(45.2)$ \\
\hline $7.5-8.4 \%(58-68 \mathrm{mmol} / \mathrm{mol})$ & $206(20.8)$ \\
\hline $8.5 \%$ or more $(69 \mathrm{mmol} / \mathrm{mol}$ or more $)$ & $74(7.5)$ \\
\hline Do not know & $99(10.0)$ \\
\hline \multicolumn{2}{|l|}{$\mathrm{HbA}_{1 \mathrm{c}}$ familiarity } \\
\hline $\begin{array}{l}\text { Yes, I have heard of the glucose test } \\
\left(\mathrm{HbA}_{1 \mathrm{c}}\right) \text { before }\end{array}$ & $894(90.0)$ \\
\hline $\begin{array}{l}\text { No, I have not heard of the glucose test } \\
\left(\mathrm{HbA}_{1 \mathrm{c}}\right) \text { before }\end{array}$ & $61(6.1)$ \\
\hline Do not know & $39(4.0)$ \\
\hline \multirow{2}{*}{\multicolumn{2}{|c|}{$\begin{array}{l}\text { Technical } \mathrm{HbA}_{1 \mathrm{c}} \text { understanding } \\
\text { A HbA1c of } 9 \% \ldots\end{array}$}} \\
\hline & \\
\hline $\begin{array}{l}\text { Means that my morning blood sugar was } \\
\text { also } 9 \mathrm{mmol} / \mathrm{L}\end{array}$ & $50(5.6)$ \\
\hline $\begin{array}{l}\text { Says something about how my blood } \\
\text { sugar has been in the past } 3 \text { months }\end{array}$ & $496(56.2)$ \\
\hline $\begin{array}{l}\text { Means that my blood sugar on average } \\
\text { has been } 9 \mathrm{mmol} / \mathrm{L} \text { in the past } 3 \text { months }\end{array}$ & $336(38.1)$ \\
\hline \multicolumn{2}{|c|}{ Places at risk of damage due to high blood sugar } \\
\hline Hands & $206(24.5)$ \\
\hline Feet & $878(91.7)$ \\
\hline Heart & $590(66.0)$ \\
\hline Kidneys & $755(81.1)$ \\
\hline Eyes & $906(93.6)$ \\
\hline Teeth/gums & $383(44.4)$ \\
\hline
\end{tabular}

these behaviors were regressed individually on relevant explanatory factors as described in the methods section.

Respondents stating adherence to general medical advice were more likely to be women (OR 1.7, CI 1.2 to 2.4), whereas stating a low or medium life satisfaction was associated with a $60 \%$ reduction in likelihood of adhering to general medical advice (OR 0.4 , CI 0.2 to 0.6 and OR 0.4, CI 0.3 to 0.6 ) or the treatment regimen (OR 0.5 , CI 0.3 to 0.8 and OR 0.7 , CI 0.5 to 1.0 ). Furthermore, respondents stating a low adherence to their treatment regimen were $50 \%$ more likely to report poorer heart health (OR 0.5 , CI 0.3 to 0.9 ) and were $40 \%$ more likely to have a low knowledge about the consequences of poor control in terms of long-term sequela (OR 0.6, CI 0.4 to 1.0 ).

Respondents measuring their blood glucose weekly or more often were twice as likely to have experienced at least one minor hypoglycemic event within the past month (OR 2.0, CI 1.2 to 3.3).

\section{DISCUSSION}

In this cross-sectional study, the associations between treatment beliefs, health behavior, and health outcomes targeting both glycemic control and CVD risk were examined. The average respondent was male, elderly, not attached to the labor market, with an education of
$<3$ years (Academy Profession degree level), and with diabetes for 10 years or more. The demography of the study population is highly representative of the Danish background population of insulin users with type 2 diabetes. More Danish men with type 2 diabetes (up to $60 \%$ ) than women are using insulin. ${ }^{31-33}$ In a Danish cross-sectional study $(\mathrm{n}=9951), 70 \%$ of the insulin users were outside the labor market, mainly due to retirement. ${ }^{33}$ In our study, this number was $79.6 \%$. Since age does not differ between responders and non-responders, non-retired, labor market attached insulin users seem slightly under-represented in the study population. Of the general population with diabetes (both insulin and non-insulin users) in the region of Copenhagen $(\mathrm{n}=47100), 85 \%$ have an education of 4 years or less and $42 \%$ have an income below 150000 DKK, corresponding to $95.2 \%$ and $39.6 \%$, respectively, in our study. ${ }^{34}$ We note that insulin users only, and none with type 1 diabetes, were included, which may explain the $10 \%$ difference in people with an education of 4 years or less between our study and the general diabetes population.

It was assumed that the sample population would be elderly and have a long average duration of diabetes. Although most surveys involving discrete choice experiments are web enabled, ${ }^{35}$ postal survey distribution was chosen to reach a group of respondents who may reject digital surveys. This assumption was guided by the high number of elderly citizens obtaining waivers to a recent mandatory requirement of using digital communication with the Danish public sector. ${ }^{36}$ The resulting response rate is within the expected range for the population. ${ }^{37} 38$

Health behaviors most consistently predicted health outcome. For $\mathrm{HbA}_{1 \mathrm{c}}$, smoking was the only behavior not associated with any change in glycemic control. Self-reported adherence, either to treatment or general medical advice, was associated with $\mathrm{HbA}_{1 \mathrm{c}}$ and lipid profile. The use of self-reported adherence questions of the kind applied in our study has been shown to generate valid results when compared to objective measures. ${ }^{39} 40$

A contradictory result was that while frequent home blood glucose measurement improved glycemic control and lipid profile, it was also associated with a higher risk of high BP.

In general, the respondents had a high $\mathrm{HbA}_{1 \mathrm{c}}$ understanding. In a US study $(\mathrm{n}=1233), 82 \%$ of the respondents with either type 1 or type 2 diabetes had heard of $\mathrm{HbA}_{1 \mathrm{c}}$ previously. ${ }^{14}$ In a similar study in the $\mathrm{UK}^{41}$ two-thirds of type 2 diabetes insulin users were unfamiliar with $\mathrm{HbA}_{1 \mathrm{c}}$. Only $13 \%$ of these could correctly interpret $\mathrm{HbA}_{1 \mathrm{c}}$ in terms of its association with blood glucose during the preceding 3 months versus $56 \%$ in the present study. We used the exact same measure for technical $\mathrm{HbA}_{1 \mathrm{c}}$ understanding but, unlike these authors, did not establish an association with either educational level or income. ${ }^{41}$ Respondent's self-stated target $\mathrm{HbA}_{1 \mathrm{c}}$ was highly predictive of actual $\mathrm{HbA}_{1 \mathrm{c}}$, but we did not 
measure if respondents knew their $\mathrm{HbA}_{1 \mathrm{c}}$ levels. Others doing so, did not find that knowledge of one's $\mathrm{HbA}_{1 \mathrm{c}}$ level translated into improved diabetes self-management. ${ }^{42}$

This study is in line with other research applying social cognition theory to identify barriers to treatment and explore individual psychosocial and behavioral modifiers of health outcomes. We found that patients who experience the treatment as cumbersome have lower treatment adherence and higher $\mathrm{HbA}_{1 \mathrm{c}}$ levels. This is in line with other studies showing a high burden on people with diabetes related to interference of diabetes medications in daily life ${ }^{1}$ and links between this burden and skipping insulin injections. ${ }^{43}$ Also, respondents stating themselves as satisfied with moderate glycemic control (or did not know which level they were satisfied with) tended to have actual $\mathrm{HbA}_{1 \mathrm{c}}$ measurements reflecting these statements.

While most treatment beliefs and health behaviors were associated with $\mathrm{HbA}_{1 \mathrm{c}}$, only a few predicted metabolic control associated with both glycemic and CVD risk targets. Since people with diabetes are at a high risk of CVD, these results indicate that attention in diabetes care is needed to improve CVD risk.

These findings highlight potential opportunities for improving care and support for people with diabetes.

First, they highlight simple self-reported indicators of poor adherence which may be useful for the care team as part of ongoing diabetes care to identify individuals in need of additional self-management support. These are tools often lacking in primary care. ${ }^{445}$

Second, our finding that patient understanding of health consequences of poor glycemic control was more strongly associated with adherence than a technical understanding of $\mathrm{HbA}_{1 \mathrm{c}}$ suggests that diabetes education, which is focused on the direct relevance of markers for the patients' health, may be most effective.

This study was not without limitations. The study data represented one-third of the full population invited to take part in the survey. However, further research is needed to evaluate characteristics of the nonresponders. Owing to the cross-sectional design of the study, causal relationships cannot be examined, nor temporality of effects. Since associations between a snapshot of health beliefs and behaviors and registry-based health outcomes measured at various points in time were evaluated, bias was mitigated by only including health outcomes obtained $<1$ year prior to survey completion.

The generalizability of the results include (1) the particular demographics, and (2) the healthcare setting of the study population. The study population was elderly and many were retired, which limited the analysis of socioeconomic factors, such as income and labor market attachment. This is a general challenge in the population of insulin users, although others have reported an association between socioeconomic status and adherence in diabetes management. ${ }^{42}$ This tendency was observed, but further examination was limited by the small sample of individuals available for the analysis. Furthermore, the diabetes model on Funen is well established with a high level of supportive diabetes services and education made available. Thus, the treatment beliefs observed in the study population may not be representative of other health systems.

\section{CONCLUSION}

Health behaviors were stronger predictors of health outcome than treatment beliefs. Self-reported adherence to either the treatment regimen or general medical advice most consistently predicted metabolic control of glycemic levels and cardiovascular risk factors. These findings are based on associations only, but nevertheless detail predictive behaviors which could be targeted for improvement with the hope of better health outcomes.

Contributors L-BWvA conducted the focus groups, developed the survey instrument, executed the data collection, researched the data, and wrote the manuscript. HG contributed to the focus groups, development of the survey instrument, and review of the statistical procedures. SS contributed to conceptualizing the study and to writing and reviewing the drafts and final manuscript.

Funding Funding for this study was provided as part of a research grant co-funded by the Danish Ministry of Education and Novo Nordisk A/S. This work was supported by Innovation Fund Denmark (Department of the Ministry of Higher Education and Science) and Novo Nordisk A/S as part of a public-industrial co-funded $\mathrm{PhD}$ project.

Disclaimer The funders did not have a role in the conduct or report of the study. Publication of the study results was not dependent on the approval of either of the funders.

Competing interests The co-authors are full-time employes at Novo Nordisk A/S, a pharmaceutical company manufacturing diabetes treatments.

Ethics approval Ethics Committee of Southern Denmark (Videnskabsetiske Komitéer for Region Syddanmark).

Provenance and peer review Not commissioned; externally peer reviewed.

Data sharing statement No additional data are available.

Open Access This is an Open Access article distributed in accordance with the Creative Commons Attribution Non Commercial (CC BY-NC 4.0) license, which permits others to distribute, remix, adapt, build upon this work noncommercially, and license their derivative works on different terms, provided the original work is properly cited and the use is non-commercial. See: http:// creativecommons.org/licenses/by-nc/4.0/

\section{REFERENCES}

1. Nicolucci A, Kovacs BK, Holt RI, et al. Diabetes Attitudes, Wishes and Needs second study (DAWN2): cross-national benchmarking of diabetes-related psychosocial outcomes for people with diabetes. Diabet Med 2013;30:767-77.

2. Stuckey HL, Mullan-Jensen CB, Reach G, et al. Personal accounts of the negative and adaptive psychosocial experiences of people with diabetes in the second Diabetes Attitudes, Wishes and Needs (DAWN2) Study. Diabetes Care 2014;37:2466-74.

3. Rosenstock IM. Historical origins of the health belief model. Health Educ Behav 1974;2:328-35.

4. Bloom Cerkoney KA, Hart LK. The relationship between the health belief model and compliance of persons with diabetes mellitus. Diabetes Care 1980;3:594-8.

5. Janz NK, Becker MH. The Health Belief Model: a decade later. Health Educ Q 1984;11:1-47.

6. Bandura A. Self-efficacy: toward a unifying theory of behavioral change. Psychol Rev 1977;84:191-215. 
7. Ajzen I. The theory of planned behavior. Organ Behav Hum Decis Process 1991;50:179-211.

8. Chao J, Nau DP, Aikens JE, et al. The mediating role of health beliefs in the relationship between depressive symptoms and medication adherence in persons with diabetes. Res Social Adm Pharm 2005;1:508-25.

9. Farmer A, Kinmonth AL, Sutton S. Measuring beliefs about taking hypoglycaemic medication among people with type 2 diabetes. Diabet Med 2006;23:265-70.

10. Adejoh SO. Diabetes knowledge, health belief, and diabetes management among the Igala, Nigeria. SAGE Open 2014;4.

11. Alogna M. Perception of severity of disease and health locus of control in compliant and noncompliant diabetic patients. Diabetes Care 1980;3:533-4

12. Nicolucci A, Carinci F, Ciampi A. Stratifying patients at risk of diabetic complications: an integrated look at clinical, socioeconomic and care-related factors. SID-AMD Italian Study Group for the Implementation of the St. Vincent Declaration. Diabetes Care 1998;21:1439-44.

13. de Weerdt I, Visser AP, Kok G, et al. Determinants of active self-care behaviour of insulin treated patients with diabetes: implications for diabetes education. Soc Sci Med 1990;30:605-15.

14. Heisler M, Piette JD, Spencer M, et al. The relationship between knowledge of recent $\mathrm{HbA1c}$ values and diabetes care understanding and self-management. Diabetes Care 2005;28:816-22.

15. Masaki Y, Okada S, Ota Z. Importance of attitude evaluation in diabetes patient education. Diabetes Res Clin Pract 1990;8:37-44.

16. Osborn CY, Egede LE. Validation of an

Information-Motivation-Behavioral Skills model of diabetes self-care (IMB-DSC). Patient Educ Couns 2010;79:49-54.

17. Daly JM, Hartz AJ, Xu Y, et al. An assessment of attitudes, behaviors, and outcomes of patients with type 2 diabetes. J Am Board Fam Med 2009;22:280-90.

18. Harris R, Linn MW. Health beliefs, compliance, and control of diabetes mellitus. South Med J 1985;78:162-6.

19. Mann DM, Ponieman D, Leventhal $\mathrm{H}$, et al. Predictors of adherence to diabetes medications: the role of disease and medication beliefs. $J$ Behav Med 2009;32:278-84.

20. Bains SS, Egede LE. Associations between health literacy, diabetes knowledge, self-care behaviors, and glycemic control in a low income population with type 2 diabetes. Diabetes Technol Ther 2011:13:335-41.

21. Stark CS, Rios BN, Geiss LS, et al. Diabetes knowledge and its relationship with achieving treatment recommendations in a national sample of people with type 2 diabetes. Diabetes Care 2012;35:1556-65.

22. Persell SD, Keating NL, Landrum MB, et al. Relationship of diabetes specific knowledge to self-management activities, ambulatory preventive care, and metabolic outcomes. Prev Med 2004:39:746-52.

23. Beck-Nielsen H. Shared-care. Presentation given at the HOPE (European Hospital and Healthcare Federation) exchange programme 2010. 2014.

24. Hoelzel W, Weykamp C, Jeppsson JO, et al. IFCC reference system for measurement of hemoglobin A1c in human blood and the national standardization schemes in the United States, Japan, and Sweden: a method-comparison study. Clin Chem 2004;50:166-74.

25. Dansk Selskab for Almen Medicin (DSAM), Dansk Endokrinologisk Selskab (DES) og Institut for Rationel Farmakoterapi (IRF). Guidelines for type 2-diabetes. En fælles behandlingsvejledning med enslydende kliniske behandlingsmål. 2014.
26. Cederholm J, Eeg-Olofsson K, Eliasson B, et al. Risk prediction of cardiovascular disease in type 2 diabetes: a risk equation from the Swedish National Diabetes Register. Diabetes Care 2008:31:2038-43.

27. Statistics Denmark. Danmarks Statistiks uddannelsesklassifikation. DISCED-15. 15-1-2015. 20-9-2015.

28. Statistics Denmark. Danmarks Statistik fagklassifikation. DISCO-08. 1-3-2011.

29. Wittrup-Jensen KU, Lauridsen JT, Gudex C, et al. Estimating Danish EQ-5D tariffs using the time trade-off (TTO) and visual analogue scale (VAS) methods. Paper presented at the 18th Plenary Meeting of the EuroQol Group; 2001. http://www euroqol org/uploads/media/ Proc01Copen20WittrupJensen pdf.

30. Olivier J, Johnson WD, Marshall GD. The logarithmic transformation and the geometric mean in reporting experimental IgE results: what are they and when and why to use them? Ann Allergy Asthma Immunol 2008;100:333-7.

31. Stovring $\mathrm{H}$, Andersen $\mathrm{M}$, Beck-Nielsen $\mathrm{H}$, et al. Rising prevalence of diabetes: evidence from a Danish pharmacoepidemiological database. Lancet 2003;362:537-8.

32. Statens Serum Instititut (SSI). Markant stigende forbrug af lægemidler mod diabetes 1999 til 2008. 2009.

33. Domgaard M, Bagger M, Rhee NA, et al. Individual and societal consequences of hypoglycemia: a cross-sectional survey. Postgrad Med 2015;127:438-45.

34. Region Hovedstaden. Forskningscenter for Forebyggelse og Sundhed. Sundhedsprofil for Regioner og Kommuner 2008. 2008.

35. von Arx LB, Kjaer T. The patient perspective of diabetes care: a systematic review of stated preference research. Patient 2014;7:283-300.

36. Digitaliseringsstyrelsen (The Danish Agency for Digitisation). Ugentlig statistik om Digital Post (Weekly statistic on digital mail). 2015. 19-3-2015.

37. Currie CJ, Poole CD, Woehl A, et al. The health-related utility and health-related quality of life of hospital-treated subjects with type 1 or type 2 diabetes with particular reference to differing severity of peripheral neuropathy. Diabetologia 2006;49:2272-80.

38. Summers KH, Szeinbach SL, Lenox SM, et al. Preference for insulin delivery systems among current insulin users and nonusers. Clin Ther 2004;26:1498-505.

39. Garfield S, Clifford S, Eliasson L, et al. Suitability of measures of self-reported medication adherence for routine clinical use: a systematic review. BMC Med Res Methodol 2011;11:149.

40. Gonzalez JS, Schneider HE, Wexler DJ, et al. Validity of medication adherence self-reports in adults with type 2 diabetes. Diabetes Care 2013;36:831-7.

41. Iqbal N, Morgan $\mathrm{C}$, Maksoud $\mathrm{H}$, et al. Improving patients' knowledge on the relationship between $\mathrm{HbA} 1 \mathrm{c}$ and mean plasma glucose improves glycaemic control among persons with poorly controlled diabetes. Ann Clin Biochem 2008:45:504-7.

42. Nam S, Chesla C, Stotts NA, et al. Barriers to diabetes management: Patient and provider factors. Diabetes Res Clin Pract 2011;93:1-9.

43. Peyrot M, Rubin RR, Kruger DF, et al. Correlates of insulin injection omission. Diabetes Care 2010;33:240-5.

44. Svarstad BL, Chewning BA, Sleath BL, et al. The Brief Medication Questionnaire: a tool for screening patient adherence and barriers to adherence. Patient Educ Couns 1999;37:113-24.

45. Copher R, Buzinec P, Zarotsky V, et al. Physician perception of patient adherence compared to patient adherence of osteoporosis medications from pharmacy claims. Curr Med Res Opin 2010;26:777-85. 